\title{
Analisis Kesejahteraan Keluarga Usaha Budidaya Ikan Keramba Di Danau Teluk Kota Jambi
}

\author{
M. Zahari ${ }^{1 *}$, Hasminidiarty ${ }^{2}$, Adria Wuri Lastari ${ }^{3}$ \\ ${ }^{1,2}$ Fakultas Ekonomi Universitas Batanghari \\ ${ }^{3}$ Universitas Adiwangsa Jambi \\ *Correspondence email: m.zaharims@gmail.com
}

\begin{abstract}
This study took place in Teluk Lake Jambi City, with the aim of: (1) knowing the condition of the cage fish farming business based on the number and area of cages owned, the workforce used, business capital, as well as production results and income, (2) Analyzing the level of family welfare as measured by the income level of fish farmers. Cages, and (3) to analyze the effect of working capital, labor, cage area and production on the welfare of the family of caged fish farming business. This research is a survey research on a sample of 50 respondents of caged fish cultivators in Teluk Lake, Jambi City. Data analysis used multiple regression, and the hypothesis was tested by $F$ test and t test. The results showed that most of the cage fish farmers used their own capital, employed around 1-2 people, the average cage area was $74.74 \mathrm{~m} 2$ per farmer, and the production that could be produced reached 2.08 tons per harvest. The income received by farmers has exceeded the Jambi City Minimum Wage. The results of hypothesis testing prove that capital, labor, cage area, and production affect the welfare of family cage fish farming in Teluk Lake, Jambi City. Given that it is important to develop cage fish cultivation in order to improve family welfare, a government policy is needed to provide capital assistance and foster cage fish farming businesses in Teluk Lake, Jambi City.
\end{abstract}

Keywords: Family welfare; fish farming; caged fish farmers

\section{PENDAHULUAN}

Kesejahteraan selalu jadi harapan bagi semua orang atau masyarakat, termasuk bagi suatu negara. Kesejahteraan bagi sebagian masyarakat sering dikaitkan dengan konsepsi kualitas hidup. Kualitas hidup adalah gambaran tentang kondisi kehidupan yang lebih baik (Zahari, et al, 2018). Dalam Wikipedia, istilah sejahtera diartikan menunjukkan suatu kondisi manusia yang terbaik yaitu dalam kondisi yang makmur, sehat maupun dalam suasana damai. Kesejahteraan adalah kemampuan yang dimiliki dalam mengatur pengeluaran guna memenuhi kebutuhan, baik pangan maupun non pangan (Zahari, et al, 2018). Oleh karenanya, kesejahteraan merupakan tujuan dari seluruh keluarga dalam upaya pemenuhan kebutuhan pokok hidup sehari-hari. Namun, permasalahannya setiap orang dalam mengarungi perjalanan kehidupannya tidak semuanya dapat mencapai kesejahteraan tersebut. Pahitnya kehidupan yang dirasakan sebagian orang membuat mereka harus selalu berusaha sekuat tenaga untuk bisa bertahan hidup dan mencari cara yang terbaik agar tetap dapat memenuhi kebutuhan hidup. Tidak melihat apakah itu mereka sebagai pekerja kasar misalnya buruh atau petani dan sejenisnya, dengan penghasilannya yang tidak menentu, hingga pekerja kantor yang menerima gaji tetap. Keluarga yang bekerja sebagai budidaya ikan seharusnya mendapatkan perhatian untuk dapat meningkatkan kesejahteraannya tersebut. Usaha budidaya ikan memiliki fungsi untuk menambah pendapatan dan kesejahteraan masyarakat. Oleh sebab itu, agar bisa memenuhi akan kebutuhan pokok hidup diperlukan biaya yang cukup, maka sebagian masyarakat untuk melakukan pembudidayaan ikan dengan sistem karamba.

Pengembangan potensi perikanan bisa dilakukan dengan aktivitas penangkaran atau pembudidayaan perikanan. Diperbandingkan dengan usaha penangkapan, maka kegiatan pembudidaya ikan ini bisa berperan sebagai lebih nyata guna penyediaan produk perikanan dengan lebih terencana serta kontinyu (Yudha, et al, 2014). Daryanto (2007) menyatakan, sumber daya sektor perikanan ialah sebagai sumberdaya terpenting untuk memenuhi hajat hidup bagi masyarakat serta memiliki potensi guna bisa dijadikan sebagai pendorong utama bagi ekonomi nasional. Kondisi ini didasari atas kenyataan dimana Indonesia memiliki potensi besar akan sumber daya dari perikanan, baik ditinjau atas apsek kuantitas ataupun diversitas.

Kota Jambi termasuk daerah yang mempunyai potensi besar untuk bisa dikembangkan menjadi sentra pembudidayaan perikanan air danau dengan menggunakan alat penangkarannya berupa keramba. Usaha ikan keramba ini memanfaatkan perairan danau atau sungai seperti di Danau Teluk dan pinggirian Sungai Batanghari. Lokasi Danau Teluk sangat cocok sebagai pengembangan pembudidayaan ikan keramba karena luas dan letaknya sangat strategis serta mudah dijangkau kendaraan darat roda 2 (motor) maupun roda 4 (mobil) serta kendaraan air berupa motor ketek. Potensi perikanan untuk jenis usaha pembudidayaan ikan keramba di danau Teluk Kota Jambi memiliki peluang pasar yang cukup menguntungkan.

Perkembangan usaha pembudidayaan ikan keramba ini terlihat dengan semakin meningkatnya jumlah keramba ikan yang tersedia di danau Teluk Kota 
Jambi selama beberapa tahun terakhir. Pada tahun 2015 baru 159 unit keramba dan pada tahun 2020 sebanyak 248 unit keramba atau terjadi peningkatan sebesar $55,97 \%$. Peningkatan jumlah keramba ini diikuti pula oleh peningkatan jumlah petani budidaya ikan keramba yaitu tahun 2015 berjumlah 42 petani ikan keramba dan pada tahun 2020 berjumlah 112 petani ikan keramba, berarti telah terjadi peningkatan sebesar 166,67\%. Produksi ikan ikan keramba yang dapat dihasilkan selama periode pengamatan mencapai rata-rata 285,16 ton, dan modal yang dikeluarkan dengan rerata sebesar Rp. 1.102.400,- per keramba.

Potensi yang besar ini apabila mampu dioptimalkan akan memberikan suatu nilai tambah yang besar, terutama masyarakat yang berada di sekitar Danau Teluk Kota Jambi. Untuk itu, guna meningkatkan hasil produksi ikan di Danau Teluk Kota Jambi tersebut dibutuhkan upaya oleh berbagai pihak terkait, karena peningkatan jumlah keramba sudah barang tentu berdampak terhadap penggunaan tenaga kerja dan kesempatan peluang usaha lebih besar bagi masyarakat. Peningkatan produksi ini akan dapat berpengaruh bagi pendapatan usaha pembudidayaan ikan keramba di Danau Teluk Kota Jambi. Pendapatan yang tinggi ini akan dapat pula memenuhi kebutuhan keluarga seharihari seperti untuk kebutuhan bahan pokok, biaya Pendidikan anak dan pembelian obatan-obatan untuk menjaga Kesehatan keluarga.

Terpenuhi kebutuhan ini menandakan terjadinya peningkatan kesejahteraan keluarga bagi petani usaha pembudidayaan ikan keramba di Danau Teluk Kota Jambi. Dalam menjalani usaha budidaya ikan keramba ini, tidak dapat dipisah dari adanya resiko yang dialami yaitu ketergantungan yang tinggi terhadap kondisi alam. Disamping kondisi alam ini, dalam melakukan budidaya ikan keramba juga memiliki kendala seperti kondisi modal untuk penyediaan bibit, pembuatan keramba, dan pemeliharaan/penyediaan pakan, dan hasil produksi apakah telah dapat meningkatkan kesejahteraan keluarga usaha pembudidayaan ikan keramba di Danau Teluk Kota Jambi.

Berangkat dari informasi tersebut penulis tertarik untuk mengkajinya lebih lanjut, dengan bertujuan untuk menganalisis tingkat kesejahteraan keluarga usaha pembudidayaan ikan keramba di Danau Teluk Kota Jambi berdasarkan indikator pendapatan yang meliputi modal, tenaga kerja, jumlah keramba dan produksi.

\section{METODE}

\section{Lokasi dan Waktu Penelitian}

Penelitian ini berlokasi di Danau Teluk Kota Jambi. Waktu penelitian dilaksanakan dalam waktu 6 bulan yaitu mulai Maret hingga Agustus 2021.

\section{Jenis data dan Sumbernya}

Adapun jenis data penelitian ini meliputi: 1) data sekunder, 2) data primer. Data sekunder adalah data pendukung yang sudah tersedia atau dipublikasikan oleh Kantor Kecamatan Danau Teluk, dan Dinas Pertanian Kota Jambi. Data primer didapat langsung ke responden dengan penyebaran kuesioner, guna mendapatkan informasi mengenai; karakteristik responden, modal usaha, tenaga kerja, luas keramba, produksi ikan, dan pendapatan, serta tingkat kesejahteraan keluarga petambak ikan keramba.

\section{Metode Penarikan Sampel}

Sampel ialah bagian dari populasi (Sudirman, et al, 2020). Penelitian ini mengambil sampel berjumlah 50 responden yang merupakan petani budidaya ikan keramba yang berada di kawasan Danau Teluk Kota Jambi. Teknik penentuan sampel dilakukan dengan acak (random sampling).

\section{Metode Analisis Data}

Analisis tingkat kesejahteraan keluarga diproksi dari pendapatan yang diterima petani. Pendapatan petani diperoleh dari nilai produksi, setelah dikurungi biaya produksi berupa modal usaha, tenaga kerja, penyediaan keramba, dan biaya panen. Analisis data dilakukan dengan pendekatan deskriptif dan kuantitatif. Analisis deskriptif diperlukan guna menganalisis dari data yang dikumpulkan seperti adanya dan tanpa bermaksud membuatkan kesimpulan dari suatu berlaku secara umum atau secara generalisasi (Sugiyono, 2009). Analisis kuantitatif dipergunakan untuk mengalisis apakah variabel bebas dapat mempengaruhi variabel terikat. Analisis data dapat dilakukan secara manual, maupun dengan menggunakan program-program komputer (Suliyanto, 2018). Dalam penelitian analisis data (pengolahan data) dibantu dengan program SPSS versi 22.0. Alat analisisnya digunakan model regresi berganda, sedangkan pengujian hipotesis dilakukan dengan uji F maupun uji t. Formulasi model persamaan regresi berganda yaitu:

$\operatorname{LnY}=\beta_{0}+\beta_{1} \operatorname{Ln} X_{1}+\beta_{2} \operatorname{Ln} X_{2}+\beta_{3} \operatorname{Ln} X_{3}+\beta_{4} \operatorname{Ln} X_{4}+e$

Keterangan:

$\mathrm{Y}=$ Kesejahteraan Keluarga

$\mathrm{X}_{1}=$ Modal

$\mathrm{X}_{2}=$ Tenaga kerja

$\mathrm{X}_{3}=$ Luas keramba

$\mathrm{X}_{4}=$ Produksi ikan

$\beta_{0}=$ Konstanta

$\beta_{1 \ldots} \beta_{4}=$ Koefisien Regresi

$\mathrm{Ln}=\mathrm{An} \log$

$\mathrm{e}=$ Error

Uji $\mathrm{R}^{2}$ (koefisien determinasi) diperuntukan melihat besarnya variasi dari variabel independent mampu menerangkan variabel dependent. Pengujian hipotesis dilakukan dengan uji $\mathrm{F}$ maupun uji t, dengan derajat tingkat kepercayaan $(\alpha)$ yaitu 0,05 .

HASIL DAN PEMBAHASAN

Karakteristik Responden 


\section{Usia Responden}

Berdasarkan jumlah responden pembudidaya ikan keramba, terbanyak berada pada kelompok umur antara umur 38 hingga 42 tahun yaitu 15 responden atau sebesar 30 persen, dan terkecil berada pada kelompok $53-57$ tahun yaitu 2 responden (4 persen). Secara rata-rata umur responden adalah berusia 43 tahun. Melihat struktur umur responden diatas, maka dapat dikatakan bahwa secara umum petani ikan keramba di Danau Teluk Kota Jambi berada pada golongan umur yang masih sangat produktif atau sedang semangatsemangatnya dalam mencari nafkah.

\section{Jumlah Anggota Keluarga (Tanggungan) Responden}

Berdasarkan jumlah tanggungan atau anggota keluarga, proporsi jumlah responden terbesar berada pada jumlah anak antara $3-4$ orang yaitu 29 responden (58 persen). Sementara proporsi responden terkecil berada pada yang mempunyai anak antara $1-2$ orang yaitu sebanyak 2 responden (4 persen) dari seluruh jumlah responden yang ada. Masih banyaknya tanggungan keluarga ini diakibatkan ada sebagian masyarakat (pembudidaya) masih beranggapan apabila banyak anak dapat mendatangkan banyak rejeki.

\section{Pendidikan Responden}

Berdasarkan tingkat Pendidikan, proporsi responden terbesar berada pada pendidikan SD yaitu 36 responden (72 persen), bahkan ada 1 responden yang tidak bersekolah. Artinya tingkat pendidikan dari responden masih tergolong sangat rendah, yaitu hanya menamatkan SD sederajat. Kondisi ini sudah barang tentu akan mempengaruhi pola pikir petani, terutama dalam pengembangan usaha budidaya ikan keramba dan pemasaran hasil produksinya.

\section{Kondisi Usaha Ikan Keramba Modal Usaha}

Modal usaha akan menentukan kelangsungan usaha budidaya ikan keramba, karena dengan modal yang mencukupi akan semakin besar kemungkinan dilaksanakannya pola intensifikasi pembudidayaan ikan keramba, seperti pembuatan keramba pembibitan, penyediaan pakan ikan, dan tenaga kerja. Berdasarkan hasil penelitian terhadap responden diketahui modal usaha yang digunakan pembudidayaan ikan keramba di Danau Teluk Kota Jambi, pada tabel 1:

Tabel 1. Modal Usaha Pembudidayaan Ikan Keramba

\begin{tabular}{ccc}
\hline $\begin{array}{c}\text { Modal Usaha } \\
(\mathbf{R p})\end{array}$ & $\begin{array}{c}\text { Frekuensi } \\
(\text { Orang) }\end{array}$ & $\begin{array}{c}\text { Persentase } \\
(\boldsymbol{\%})\end{array}$ \\
\hline $400.000-850.000$ & 11 & 22 \\
$851.000-1.300 .000$ & 23 & 46 \\
$1.301 .000-1.750 .000$ & 8 & 16 \\
$1.751 .000-2.200 .000$ & 3 & 6 \\
$2.201 .000-2.650,000$ & 5 & 10 \\
Jlh & 50 & 100 \\
\hline
\end{tabular}

Sumber: Pengolahan data Primer
Proporsi modal usaha yang digunakan responden sebagaian besar berada pada kisaran modal antara Rp. 851.000 - Rp 1.300.000, ada 23 responden (46 persen). Sementara proporsi modal antara Rp. 1.751 .000 2.200.000 berjumlah 3 responden (6 persen). Rata-rata modal usaha yang dimiliki responden adalah sebesar Rp. 1.239 .400

\section{Tenaga Kerja}

Pada umumnya tenaga kerja dipergunakan untuk usaha pembudidayaan ikan keramba di Danau Teluk Kota Jambi berasal dari keluarga petambak itu sendiri. Jumlah tenaga kerja yang gunakan sebagaian besar kisaran jumlah 1-2 orang yaitu mencapai 74 persen atau 37 responden. Kondisi ini tergambar pada table 2 berikut:

Tabel 2. Tenaga Kerja Usaha Pembudidayaan Ikan Keramba

\begin{tabular}{ccc}
\hline $\begin{array}{c}\text { Jumlah Tenaga } \\
\text { Kerja (Orang) }\end{array}$ & $\begin{array}{c}\text { Frekuensi } \\
\text { (Orang) }\end{array}$ & $\begin{array}{c}\text { Persentase } \\
(\mathbf{\%})\end{array}$ \\
\hline $1-2$ & 37 & 74 \\
$3-4$ & 12 & 24 \\
$5-6$ & 1 & 2 \\
$>6$ & 0 & 0 \\
Jlh & 50 & 100 \\
\hline
\end{tabular}

Sumber: Pengolahan data Primer

\section{Luas Keramba}

Luas keramba dapat juga mejadi penentu dalam meningkatkan produksi usaha pembudidaya ikan keramba. Dimana semakin luas keramba yang tersedia, maka bibit ikan banyak yang bisa ditebarkan, dan diharapkan dapat meningkatkan produksi ikan keramba. Luas keramba yang dipunyai responden, terdilihat di tabel 3 berikut:

Tabel 3. Luas Keramba

\begin{tabular}{ccc}
\hline Luas Keramba $\left(\mathbf{M}^{\mathbf{2}}\right)$ & Frekuensi & Persentase (\%) \\
\hline $30-43,57$ & 5 & 10 \\
$43,58-57,15$ & 9 & 18 \\
$57,16-70,73$ & 16 & 32 \\
$70,74-84,31$ & 5 & 10 \\
$84,32-97,89$ & 3 & 6 \\
$97,90-111,47$ & 0 & 0 \\
$111,48-125$ & 12 & 24 \\
Jlh & 50 & 100 \\
Rata-rata Luas Keramba & \multicolumn{2}{c}{$74,74 \mathrm{~m}^{2}$} \\
\hline
\end{tabular}

Sumber: Pengolahan data Primer

Data pada tabel 3, menunjukkan sebagian besar responden memiliki luas keramba dalam kisaran 57,16$70,73 \mathrm{~m}^{2}$ yaitu 16 responden atau sebesar 32 persen. Rata-rata luas keramba yang dimiliki responden adalah seluas $74,74 \mathrm{~m}^{2}$. 


\section{Produksi Ikan Keramba}

Produksi ikan keramba merupakan hasil panen dari usaha pembudidayaan ikan keramba yang telah dipelihara jangka waktu tertentu. Semakin besar hasil penen ikan keramba dan bisa dijual, maka dimungkinkan pendapatan yang petani diterima makin besar pula. Sebaliknya apabila hasil panen ikan keramba sedikit atau tidak terjual, maka semakin rendah pendapatan petani, bahkan bisa rugi.

Untuk mengetahui hasil produksi ikan keramba per musim panen di Danau Teluk Kota Jambi, sebagai tabel 4 berikut:

Tabel 4. Produksi Usaha Budidaya Ikan Keramba

\begin{tabular}{ccc}
\hline $\begin{array}{c}\text { Jumlah Produksi Ikan } \\
\text { Keramba /Musim Panen (Kg) }\end{array}$ & Frekuensi & $\begin{array}{c}\text { Persentase } \\
(\boldsymbol{\%})\end{array}$ \\
\hline $300-1.760$ & 13 & 26 \\
$1.761-3.220$ & 24 & 48 \\
$3.221-4.680$ & 6 & 12 \\
$4.681-6.140$ & 6 & 12 \\
$6.141-7.600$ & 1 & 2 \\
Jlh & 50 & 100 \\
\hline
\end{tabular}

Sumber: Pengolahan data Primer

Dari data terlihat bahwa ada 24 responden (48 persen) yang hasil produksi ikan kerambanya mencapai $1.761-3.220 \mathrm{Kg}$. Secara rata-rata jumlah produksi ikan keramba di Danau Teluk Kota Jambi adalah sebesar $2.086,22 \mathrm{Kg}$.

\section{Pendapatan Usaha Budidaya Ikan Keramba}

Pendapatan yang diperoleh petani dalam usaha budidaya ikan keramba merupakan salah satu faktor penentu keberhasilan dan keberlangsungan dari usaha budidaya ikan keramba yang dijalankan. Pendapatan yang diterima petani merupakan pendapatan bersih, yaitu pendapatan yang diperoleh setelah dikurangi dengan beban biaya produksi. Adapun pendapatan bersih perbulan yang diperoleh petani budidaya ikan keramba di Danau Teluk, tergambar di Tabel 5 berikut:

Tabel 5. Pendapatan Petani Usaha Budidaya Ikan Keramba

\begin{tabular}{ccc}
\hline Pendapatan (Rp) & $\begin{array}{c}\text { Frekuensi } \\
\text { (Orang) }\end{array}$ & $\begin{array}{c}\text { Persentase } \\
(\%)\end{array}$ \\
\hline $1.470 .000-2.360 .000$ & 8 & 16 \\
$2.370 .000-3.260 .000$ & 17 & 34 \\
$3.270 .000-4.160 .000$ & 12 & 24 \\
$4.170 .000-5.060 .000$ & 3 & 6 \\
$5.070 .000-5.960 .000$ & 2 & 4 \\
$5.970 .000-6.860 .000$ & 5 & 10 \\
$6.870 .000-7.700 .000$ & 3 & 6 \\
Jlh & 50 & 100 \\
\hline
\end{tabular}

Sumber: Pengolahan data Primer

Berdasarkan data pada Tabel 5 menerangkan bahwa pendapatan bersih per-bulan terbesar yang diperoleh petani budidaya ikan keramba berada pada kisaran Rp. 6.870.000 - Rp. 7.700.000, dengan distribusi frekuensi sebesar 3 orang atau 6\%. Pendapatan bersih per-bulan terkecil yang diperoleh petani budidaya ikan keramba berada pada kisaran Rp. 1.470.000 - Rp. 2.360.000, dengan distribusi frekuensi sebesar 8 orang atau $16 \%$. Dari data tersebut diketahui pula bahwa sebagian besar petani budidaya ikan keramba memperoleh pendapatan bersih per-bulannya pada kisaran Rp. 2.370.000 - Rp. 3.260.000, dengan distribusi frekuensi sebesar 17 orang atau $34 \%$.

\section{Analisis Kesejahteraan Keluarga Usaha Pembudidayaan Ikan Keramba Uji asumsi klasik}

Hasil uji asumsi klasik yang terdiri atas; uji normalitas, uji autokorelasi, uji multikolinearitas, dan uji heteroskedastisitas, menunjukkan bahwa model regresi berganda yang digunakan dengan formasi: $\mathrm{LnY}=$ $\beta_{0}+\beta_{1} \operatorname{LnX}_{1}+\beta_{2} \operatorname{Ln} X_{2}+\beta_{3} \operatorname{Ln} X_{3}+\beta_{4} \operatorname{Ln} X_{4}+e$, bisa dijadikan model dan memenuhi kriteria BLUE (Best Linear Unbiased Estimator).

\section{Analisis Regresi Berganda}

Untuk mengetahui pengaruh modal, tenaga kerja, luas keramba, dan produksi terhadap kesejahteraan keluarga usaha pembudidayaan ikan keramba, digunakan analisis regresi linier berganda dengan bantuan program SPSS V.22. Hasil olahan data tersebut dapat diformulasi ke dalam model persamaan regresi berganda, yaitu:

$\operatorname{LnY}=9,764+0,020 \operatorname{LnX} X_{1}+0,003 \operatorname{Ln} X_{2}+0,110 \operatorname{LnX}_{3}+0,601 \operatorname{LnX}_{4}$

Berdasarkan model persamaan regresi ini, maka didapatkan gambaran pengaruh modal usaha (X1), tenaga kerja (X2), luas keramba (X3), dan produksi (X4) terhadap kesejahteraan keluarga (Y), berikut:

1. Konstanta (a) $=9,764$, berarti bila variabel modal (X1), tenaga kerja (X2), luas keramba (X3), dan produksi (X4) tidak ada, maka kesejahteraan keluarga usaha pembudidayaan ikan keramba (Y) nilainya akan bertambah sebesar 9,764.

2. Koefisien regresi Modal usaha $\left(\beta_{1} X_{1}\right)=0,020$. Angka ini menunjukkan apabila modal usaha peningkatannya sebesar $1 \%$, maka kesejahteraan keluarga usaha pembudidayaan ikan keramba akan meningkatkan sebesar $0,020 \%$.

3. Koefisien regresi tenaga kerja $\left(\beta_{2} X_{2}\right)=0,003$, Angka ini menunjukkan apabila tenaga kerja peningkatannya sebesar $1 \%$, maka kesejahteraan keluarga usaha pembudidayaan ikan keramba akan meningkatkan sebesar $0,003 \%$.

4. Koefisien regresi luas keramba $\left(\beta_{3} X_{3}\right)=0,110$, Angka ini menunjukkan apabila luas keramba peningkatannya sebesar $1 \%$, maka kesejahteraan keluarga usaha pembudidayaan ikan keramba akan meningkatkan sebesar $0,110 \%$.

5. Koefisien regresi produksi $\left(\beta_{4} X_{4}\right)=0,601$, Angka ini menunjukkan apabila produksi peningkatannya sebesar $1 \%$, maka kesejahteraan keluarga usaha 
pembudidayaan ikan keramba akan meningkatkan sebesar $0,601 \%$.

Berdasarkan koefisien regresi tersebut, maka variabel produksi paling menentukan dalam pembentukan kesejahteraan keluarga usaha pembudidayaan ikan keramba di Danau Teluk, Kota Jambi.

\section{Uji Koefisien Determinasi $\left(R^{2}\right)$}

Koefisien determinasi $\left(\mathrm{R}^{2}\right)$ dipergunakan untuk melihat seberapa besar variasi variabel $\mathrm{X}_{\mathrm{i}}$ (modal, tenaga kerja, luas keramba, dan produksi) mampu menerangkan variabel Y (kesejahteraan keluarga). Hasil analisis uji koefisien determinasi $\left(\mathrm{R}^{2}\right)$, seperti tabel 6 :

Tabel 6. Uji Koefisien Determinasi $\left(\mathrm{R}^{2}\right)$

\begin{tabular}{|c|c|r|c|c|}
\hline Model & $R$ & R Square $^{b}$ & $\begin{array}{c}\text { Adjusted } R \\
\text { Square }\end{array}$ & $\begin{array}{c}\text { Std. Error of the } \\
\text { Estimate }\end{array}$ \\
\hline 1 & $0,851^{\mathrm{a}}$ & 0,724 & $\mathbf{0 , 7 0 0}$ & 0,23096 \\
\hline
\end{tabular}

Sumber: Pengolahan data dengan SPSS 22

Nilai koefisien determinasi (Adj. $\mathrm{R}^{2}$ ) sebesar 0,700 . Hal ini berarti variasi naik turunnya variabel kesejahteraan keluarga usaha pembudidayaan ikan keramba mampu dijelaskan oleh modal, tenaga kerja, luas keramba, dan produksi sebesar 70 persen, sementara sisanya sebesar 30 persen diterangkan oleh variabel lainnya yang tidak diteliti dalam penelitian ini. Hasil pengujian ini menerangkan bahwa variabel modal, tenaga kerja, luas keramba, dan produksi memberikan kontribusi pengaruh yang cukup besar terhadap tinggi rendahnya kesejahteraan keluarga usaha pembudidayaan ikan keramba.

\section{Uji Hipotesis}

\section{Uji F statistik}

Uji $F$ dipergunakan untuk melihat apakah secara simultan variabel modal (X1), tenaga kerja (X2), luas keramba (X3), dan produksi (X4) berpengaruh secara signifikan terhadap kesejahteraan keluarga usaha pembudidayaan ikan keramba (Y). Berikut adalah tabel hasil analisis uji $\mathrm{f}$ :

Tabel 7. Hasil Pengujian F Statistik

\begin{tabular}{|l|r|r|r|c|c|}
\hline Model & Sum of Squares & df & Mean Square & F & Sig. \\
\hline Regression & 6,309 & 4 & 1,577 & 29,566 & $\mathbf{0 , 0 0 0 ^ { \mathrm { b } }}$ \\
1 Residual & 2,400 & 45 & 0,053 & & \\
Total & 8,709 & 49 & & & \\
\hline
\end{tabular}

Sumber: Pengolahan data dengan SPSS 22

Berdasarkan Tabel 7, menunjukkan nilai signifikansi (sig) uji $\mathrm{F}$ sebesar 0,000. Angka ini menunjukkan nilai signifikansi (sig) dari uji $\mathrm{F}(0,000)$ lebih kecil dari 0,05 . Artinya secara bersama-sama modal (X1), tenaga kerja (X2), luas keramba (X3), dan produksi (X4) berpengaruh signifikan terhadap kesejahteraan keluarga usaha pembudidayaan ikan keramba (Y).

\section{Uji t Statistik}

Uji t dipergunakan untuk melihat signifikan tidaknya masing-masing variabel $\mathrm{Xi}$ (modal, tenaga kerja, luas keramba, dan produksi) terhadap variabel $\mathrm{Y}$ (kesejahteraan keluarga). Berikut adalah tabel hasil analisis uji t:

Tabel 8. Hasil Pengujian T Statistik

\begin{tabular}{|l|r|r|r|r|r|}
\hline \multirow{2}{*}{ Model } & \multicolumn{2}{|c|}{$\begin{array}{c}\text { Unstandardized } \\
\text { Coefficients }\end{array}$} & \multicolumn{1}{c|}{$\begin{array}{c}\text { Standardized } \\
\text { Coefficients }\end{array}$} & \multirow{2}{*}{$\mathrm{t}$} & \multirow{2}{*}{ Sig. } \\
\cline { 2 - 4 } & \multicolumn{1}{|c|}{ B } & \multicolumn{1}{|c|}{ Std. Error } & \multicolumn{1}{c|}{ Beta } & & \\
\hline \multirow{2}{*}{ (Constant) } & 9,764 & 0,894 & & 10,926 & $\mathbf{0 , 0 0 0}$ \\
X1 & 0,020 & 0,081 & 0,025 & 0,245 & $\mathbf{0 , 8 0 8}$ \\
X2 & 0,003 & 0,117 & 0,002 & 0,030 & $\mathbf{0 , 9 7 6}$ \\
X3 & 0,110 & 0,123 & 0,101 & 0,896 & $\mathbf{0 , 3 7 5}$ \\
X4 & 0,601 & 0,102 & 0,760 & 5,918 & $\mathbf{0 , 0 0 0}$ \\
\hline
\end{tabular}

Sumber: Pengolahan data dengan SPSS 22

Dari hasil pengujian dengan bantuan program analisis statistik SPSS 22 (Tabel 8), didapatkan nilai signifikansi (sig) untuk variabel modal (X1) sebesar 0,808 . Angka ini besar dari alpa 0,05, dengan demikian didapatkan keputusan bahwa modal usaha tidak berpengaruh signifikan terhadap variabel kesejahteraan keluarga usaha pembudidayaan ikan keramba.

Nilai signifikansi (sig) untuk variabel tenaga kerja (X2) adalah sebesar 0,976. Angka ini besar dari alpa 0,05 , dengan demikian didapatkan keputusan bahwa tenaga kerja tidak berpengaruh signifikan terhadap kesejahteraan keluarga usaha pembudidayaan ikan keramba.

Nilai signifikansi (sig) untuk variabel luas keramba (X3) adalah sebesar 0,375. Angka ini besar dari alpa 0,05, dengan demikian didapatkan keputusan bahwa luas keramba tidak berpengaruh signifikan terhadap kesejahteraan keluarga usaha pembudidayaan ikan keramba.

Nilai signifikansi (sig) untuk variabel produksi (X4) adalah sebesar 0,000. Angka ini lebih kecil dari alpa 0,05 dengan demikian didapatkan keputusan bahwa produksi berpengaruh signifikan terhadap kesejahteraan keluarga usaha pembudidayaan ikan keramba.

\section{Pembahasan \\ Pengaruh Modal, Tenaga Kerja, Luas Keramba, dan Produksi terhadap Kesejahteraan Keluarga}

Setiap kegiatan dalam mencapai tujuan membutuhkan modal apalagi kegiatan proses produksi komoditas perikanan. Semakin besar modal yang dimiliki dan dapat digunakan secara efisien dalam menjalan kegiatan usaha pembudidayaan ikan keramba, maka semakin besar pula tingkat produksi ikan yang akan diperoleh. Modal berperan penting dalam menentukan peningkatan kesejahteraan keluarga usaha dari pengusaha karena tersedianya modal yang cukup akan mempengaruhi kelancaran dan pengembangan usaha yang dijalankan. 
Faktor produksi berikutnya yang diduga dapat mempengaruhi kesejahteraan keluarga usaha pembudidayaan ikan keramba di Danau Teluk Kota Jambi adalah luas keramba. Adapun luas ideal untuk satu unit keramba yang digunakan dalam pembudidayaan ikan yaitu $3 \mathrm{~m} \times 5 \mathrm{~m}$ atau $15 \mathrm{~m}^{2}$. Total luas keramba keseluruhan merupakan hasil kali antara jumlah keramba dengan luas ideal per keramba. Semakin luas keramba yang digunakan, tentunya akan meningkatkan kapasitas produksi ikan keramba, dan dengan demikian akan meningkatkan pendapatan yang diterima petani.

Pemberian pakan yang teratur dan penjagaan kolam dalam usaha keramba menjadi kegiatan yang penting untuk meningkatkan produksi. Oleh karena itu dibutuhkan tenaga kerja yang bertugas untuk memberi pakan dan menjaga keramba agar terhindar dari resiko kematian ikan. Tenaga kerja pada usaha ikan keramba ini tergantung dari kegiatan yang dilakukan, semakin banyak keramba yang disediakan maka semakin banyak pula tenaga kerja dapat digunakan.

Modal kerja, luas keramba, dan tenaga kerja merupakan masukan (input) dari yang dapat digunakan dalam budidaya ikan keramba guna menghasilkan produk ikan keramba (output). Penggunaan modal usaha, luas keramba, dan tenaga kerja yang efisien dan efektif tentunya dapat berdampak positif bagi produksi ikan keramba. Semakin tinggi produksi ikan keramba, maka semakin tinggi pula pendapatan yang bisa diterima, dan pada giliran dapat meningkatkan kesejahteraan keluarga petani.

Berdasarkan hasil pengujian hipotesis diketahui bahwa modal usaha, tenaga kerja, luas keramba, dan produksi secara simultan berpengaruh signifikan $(0,000$ $<0,05)$ terhadap kesejahteraan keluarga usaha pembudidayaan ikan keramba. Hasil temuan ini menerangkan bahwa modal usaha, tenaga kerja, luas keramba, dan produksi saling berinteraksi dalam mempengaruhi kesejahteraan keluarga usaha pembudidayaan ikan keramba.

\section{Pengaruh Modal terhadap Kesejahteraan Keluarga}

Setiap kegiatan dalam mencapai tujuan membutuhkan modal apalagi kegiatan proses produksi komoditas perikanan. Semakin besar modal yang dimiliki dan dimanfaatkan dengan efisien, maka semakin besar pula tingkat produksi ikan yang akan diperoleh. Dengan adanya penambahan modal maka biaya operasional (input) dapat ditingkatkan dan kemungkinan (output) akan semakin besar sehingga pendapatan juga akan ikut meningkat.

Berdasarkan hasil dari pengujian hipotesin menunjukkan bahwa modal usaha berpengaruh tidak signifikan $(0,808>0,05)$ terhadap kesejahteraan keluarga usaha pembudidayaan ikan keramba. Hasil temuan ini mengidentifikasi bahwa setiap penambahan modal usaha ternyata tidak dibarengi dengan peningkatan kesejahteraan keluarga usaha pembudidayaan ikan keramba. Hasil temuan ini bertentangan dengan teori dan hasil penelitian Hikmawati (2018) menemukan bahwa modal berpengaruh signifikan terhadap pendapatan petani tambak udang. Namun, hasil penelitian ini selaras dengan hasil penelitian Ilhamdi, dkk (2020) yang menemukan bahwa modal berpengaruh tidak signifikan terhadap pendapatan petani Budidaya Ikan Mas.

\section{Pengaruh Tenaga Kerja terhadap Kesejahteraan Keluarga}

Dalam suatu kegiatan usaha keramba ikan, peran tenaga kerja sangat diperlukan sebagai salah satu penggerak dari suatu usaha. Semakin berkembangkanya suatu usaha pembudidayaan ikan keramba maka semakin besar tenaga kerja tersebut dibutuhkan. Tenaga kerja tersebut dapat diperoleh dari luar maupun tenaga kerja masih ada ikatan keluarga dari petani pemilik usaha ini (Sutrisno, 2019). Pemberian pakan yang teratur dan penjagaan keramba oleh tenaga kerja merupakan kegiatan sangat penting untuk pemeliharaan ikan keramba. Dengan demikian, dimungkinkan terhindar dari resiko kematian ikan dan hasil produksi ikan dapat ditingkatkan.

Berdasarkan hasil pengujian hipotesis diketahui bahwa tenaga kerja berpengaruh tidak signifikan $(0,976$ $>0,05)$ terhadap kesejahteraan keluarga usaha pembudidayaan ikan keramba. Hasil temuan ini menerangkan bahwa setiap penambahan jumlah tenaga kerja ternyata tidak diikuti dengan peningkatan kesejahteraan keluarga usaha pembudidayaan ikan keramba. Hasil temuan ini selaras dengan hasil penelitian Takbir, et al (2017) yang membuktikan bahwa tenaga kerja berpengaruh tidak signifikan terhadap pendapatan usaha budidaya bandeng.

Tidak berpengaruhnya tenaga kerja terhadap kesejahteraan keluarga usaha pembudidayaan ikan keramba di Danau Teluk Kota Jambi karena petani tersebut hanya membutuhkan tenaga kerja keluarga, tenaga kerja kurang berpengalaman, dan kurang terampil. Sebagian besar tenaga kerja yang dipekerjakan dalam usaha pembudidayaan ikan keramba di Danau Teluk Kota Jambi adalah berasal dari keluarga petani seperti anak dan istri, sehingga biaya yang dikeluarkan kurang karena tidak ada tenaga kerja yang disewakan.

\section{Pengaruh Luas Keramba terhadap Kesejahteraan Keluarga}

Dalam usaha pembudidayaan ikan keramba penguasaan atau kepemilikan luas keramba yang sempit sudah pasti kurang efisien dibandingkan dengan keramba yang lebih luas. Semakin sempit luas keramba yang digunakan, semakin tidak efisien usaha pembudidayaan ikan keramba dilakukan. Mantau (2004) menyatakan, penempatan keramba jaringan apung pada dasarnya harus di kedalaman air berkisar minimal antara 
2-3 $\mathrm{m}$ dan kedalaman yang optimal 5-7 $\mathrm{m}$, serta kecerahan air 1-2 m.

Hasil pengujian menunjukkan bahwa luas keramba tidak berpengaruh signifikan $(0,375>0,05)$ terhadap kesejahteraan keluarga usaha pembudidayaan ikan keramba. Hasil temuan ini menerangkan bahwa setiap peningkatan luas keramba ternyata tidak diikuti dengan peningkatan kesejahteraan keluarga usaha pembudidayaan ikan keramba. Temuan ini bertentangan dengan hasil penelitian Tajerin dan Suryana (2011), membuktikan luas areal berpengaruh signifikan terhadap peningkatan keuntungan diteriman bagi pembudidayaan ikan Kerapu Bebek. Keramba yang luas serta bisa dikelola lebih baik, tentunya akan memberikan hasil terbaik dan menguntungkan petani pembudidayaan ikan keramba. Luas keramba yang digunakan, tentunya akan meningkatkan kapasitas produksi ikan keramba dan apabila hasil panen tersebut dapat terjual semua akan dapat meningkatkan pendapatan. Peningkatan pendapatan ini akan bisa meningkatkan kesejahteraan keluarga petani.

\section{Pengaruh Produksi terhadap Kesejahteraan Keluarga}

Produksi sebagai hasil akhir dari proses atau aktivitas ekonomi dengan memanfaatkan beberapa masukan (input), atau istilah lain mengkombinasikan berbagai masukan (input) untuk menghasikan produk/jasa (output). Apabila output semakin banyak dihasilkan akan dapat berpengaruh bagi peningkatan pendapatan usaha tersebut.

Produksi ikan keramba di Danau Teluk Kota Jambi merupakan hasil kombinasi dari berbagai input, yaitu; modal, tenaga kerja, jumlah keramba, luas keramba, dan lainnya. Berdasarkan hasil pengujian hipotesis diketahui bahwa produksi berpengaruh signifikan $(0,000<0,05)$ terhadap kesejahteraan keluarga usaha pembudidayaan ikan keramba. Hasil temuan ini menerangkan bahwa setiap peningkatan jumlah produksi ikan keramba, maka akan diikuti dengan peningkatan kesejahteraan keluarga usaha pembudidayaan ikan keramba. Hasil temuan ini sejalan dengan hasil penelitian Saipal, et al (2019), membuktikan bahwa jumlah produksi berpengaruh positif dan signifikan terhadap pendapatan petani tambak Ikan Bandeng.

\section{SIMPULAN}

Berdasarkan hasil penelitian maka dapat disimpulkan yaitu:

1. Kondisi modal, tenaga kerja, luas keramba, produksi ikan, dan pendapatan usaha pembudidayaan ikan keramba di Danau Teluk Kota Jambi, diketahui ratarata modal yang dimiliki petani sebesar Rp. 1.239.400. Tenaga kerja yang digunakan sebanyak 12 orang, dengan rata-rata luas keramba ikan sebesar $74,74 \mathrm{~m}^{2}$ per petani. Adapun rata-rata produksi ikan keramba per petani di Kawasan Danau Teluk Kota
Jambi adalah sebesar 2.086,22 $\mathrm{Kg}$, dengan pendapatan bersih per bulan sebesar Rp. 2.370.000 hingga Rp. 3.260.000.

2. Berdasarkan hasil analisis $t$ statistik didapatkan bahwa variabel modal, tenaga kerja, dan luas keramba secara parsial tidak berpengaruh signifikan terhadap kesejahteraan keluarga usaha pembudidayaan ikan keramba di Danau Teluk Kota Jambi, sedangkan variabel produksi ikan secara parsial berpengaruh signifikan terhadap kesejahteraan keluarga usaha pembudidayaan ikan keramba di Danau Teluk Kota Jambi.

3. Hasil uji $F$ statistik menunjukkan bahwa secara simultan variabel modal, tenaga kerja, luas keramba, dan produksi berpengaruh signifikan terhadap kesejahteraan keluarga usaha budidaya ikan keramba di Danau Teluk Kota Jambi.

\section{Saran}

Berdasarkan uraian hasil penelitian, maka saran yang perlu disampaikan, diantaranya:

1. Bagi akademisi, mengingat beberapa variabel tidak berpengaruh signifikan terhadap kesejahteraan keluarga petani yaitu variable modal, tenaga kerja, serta luas keramba diharapkan bagi peneliti yang akan meneliti permasalahan sama untuk dapat menguji kembali keterkaitan variable modal, tenaga kerja, serta luas keramba terhadapat kesejahteraan keluarga petani usaha ikan keramba.

2. Bagi pemerintah/instansi terkaitan agar terus melakukan pembinaan terhadap para petani pembudidayaan ikan keramba, terutama terhadap bantuan modal untuk pembibitan dan pemeliharaan (penyediaan pakan), pelatihan tenaga kerja serta perluasan/penyediaan alat keramba, dengan harapan petani lebih giat dalam mengelola keramba ikan miliknya.

\section{DAFTAR PUSTAKA}

Daryanto, Arief, 2007. Dari Klaster Menuju Peningkatan Daya Saing Industri Perikanan. Buletin Craby \& Starky, Edisi Januari 2007.

Hikmawati. 2018. Pengaruh Luas Lahan, Modal Dan Tenaga Kerja Terhadap Pendapatan Petani Tambak Udang Di Desa Tamuku Kecamatan Bone-Bone Kabupaten Luwu Utara. STIE Muhammadiyah Palopo. Jurnal Ekonomi Pembangunan. Vol 4 No 1 (2018).

Ilhamdi, Hasnudi Hasnudi, Gustami Harahap. 2020. Analisis Faktor Faktor Yang Mempengaruhi Produksi Pembenihan Ikan Mas Terhadap Pendapatan Petani (Studi Kasus di Kabupaten Aceh Tenggara). Program Pascasarjana Magister Agribisnis Universitas Medan Area. AGRISAINS: Jurnal Ilmiah Magister Agribisnis. Vol 2, No 2 (2020): 129-138. 
Mantau, Zulkifli. 2004. Analisis Kelayakan Investasi Usaha Budidaya Ikan Mas Dan Nila Dalam Keramba Jaring Apung Ganda di Pesisir Danau Tondano Propinsi Sulawesi Utara.

https://konservasidanautondano.wordpress.com $/ \mathrm{m}$ akalah/zulkifli-mantau/

Saipal, M., Muchtar Surullah, Sri Wahyuni Mustafa. 2019. Faktor-Faktor Yang Mempengaruhi Pendapatan Petani Tambak Ikan Bandeng Di Desa Salekoe Kecamatan Malangke Kabupaten Luwu Utara. Jurnal Ekonomi Pembangunan Vol. 5, No. 1 (2019) 31-41

Sudirman, Osrita Hapsara, dan M. Zahari. 2020. Metodologi Penelitian Kuantitatif. Yogyakata: Magnum Pustaka Utama.

Sugiyono, 2009, Metode Penelitian Bisnis, Cetakan Kesembilan, Alfabeta Bandung.

Suliyanto. 2018. Metode Penelitian Bisnis, untuk Skripsi, Tesis, dan Disertasi. Yogyakarta: Penerbit Andi.

Sutrisno, Edy. 2019. Manajemen Sumber Daya Manusia. Jakarta: Kencana

Tajerin dan Asep Agus Handaka Suryana. 2011. Faktor Penentu Keuntungan Dan Pengukuran Skala Usaha Budidaya Ikan Kerapu Bebek (Cromileptes Altivelis) Di Kabupaten Pesawaran, Lampung. Jurnal Aktuatika, Vol 2, No 1 (2011). http://jurnal.unpad.ac.id/akuatika/article/view/505

Takbir, Madrin, Budiyanto, Roslindah Daeng Siang. 2017. Analisis Faktor-Faktor Yang Mempengaruhi Pendapatan Usaha Budidaya Bandeng Di Kecamatan Laeya Kabupaten Konawe Selatan. Jurnal Sosial Ekonomi Perikatan Vol 2, No 3 (2017).

Yudha, M., Kadarso, Ichwani Kruniasih. 2014. Analisis Pendapatan dan Kelayakan Usaha Tani Ikan Sistem Keramba di Tirtonirmolo Bantul. Agros Vol.16 No.2, Juli 2014: 264-272.

Zahari MS. M, Syamsurijal Tan, Haryadi, dan Syaparuddin. 2018. Analysis of fiscal decentralization impact on community welfare in Jambi Province. Jurnal Perspektif Pembiayaan dan Pembangunan Daerah Vol. 6. No.3, November - December 2018. 